\title{
Biological control of Golovinomyces cichoracearum, the causal pathogen of sunflower powdery mildew
}

\author{
Adel Ateyh Esawy', Mohsen Mohamed Elsharkawy ${ }^{2 *}$ (D), Reda Ibrahim Omara', Mamdouh Abdel Fattah Khalifa', \\ Fawzya Mohamed Fadel ${ }^{2}$ and Magdy Mohamed El-Naggar ${ }^{2}$
}

\begin{abstract}
Background: Powdery mildew was found in most of the sunflower fields in Egypt, causing severe yellowing of the blade, petiole, stem and calyx, as well as a considerable defoliation during the summer season of 2018. Out of the fungal mycelium from infected leaves, collected from sunflower fields in the four Egyptian Governorates (Kafr El-Sheikh, Gharbia, Giza and El-Beheira), five isolates of powdery mildew pathogen were obtained and identified using morphological and molecular identification methods.

Results: In 2019 and 2020 seasons, five biocontrol agents (Bacillus subtilis, B. pumilus, Trichoderma harzianum, T. viride and T. koningii) were used to control powdery mildew disease on sunflower plants under field conditions compared with the fungicide (Vectra 10\% SC). Treatments were significantly effective for controlling the powdery mildew disease relative to the control. The best treatment for reducing disease parameters (final disease severity (FDS\%), area under disease progress curve (AUDPC) and efficacy) than the control was T. koningii. Foliar application of all the tested treatments improved plant height, head and stem diameters and seed yield in relation to untreated plants (control). The components (FDS\%, AUDPC and efficacy) were extracted and described approximately $95.251 \%$ of the pooled data of seasons 2019 and 2020. In such pooled data, the principal components (PC1, PC2 and PC3) of all disease parameters, plant development parameters and yield components were recorded $76.305,86.635$ and $96.265 \%$ of the total variance, respectively.
\end{abstract}

Conclusion: A biological control agent, such as T. koningii, can be suggested for disease control based on the experimental findings.

Keywords: Sunflower, Powdery mildew, Golovinomyces cichoracearum, Biological control, Plant parameters

\section{Background}

Powdery mildew is a severe sunflower disease caused by Golovinomyces cichoracearum. Traditional identification techniques are time-consuming and need a great deal of expertise in distinguishing the morphologies of these fungi (Grote et al. 2002). Furthermore, the taxonomic characterizations of this disease have been confounded

\footnotetext{
*Correspondence: mohsen.abdelrahman@agr.kfs.edu.eg

${ }^{2}$ Agricultural Botany Department, Faculty of Agriculture, Kafrelsheikh University, Kafr El-Sheikh, Egypt

Full list of author information is available at the end of the article
}

by the fact that certain powdery mildew fungi develop sexual spores or have a nonsexual stage toward the conclusion of the growth season (Kashimoto et al. 2003). Differences in the sequence of nucleotides in the internal transcribed spacer (ITS) sections of rDNA, as well as PCR, using specific primers, have been utilized to detect and identify powdery mildews with a great success (Chen et al. 2008). In the late stages of infection, superficial mycelia may grow and combine, covering the majority of the plant's surface. Presently, cultural practices, chemical pesticides and resistant hybrids control powdery mildew of sunflower (Sudisha et al. 2010). However, pesticides' 
usage leads to the development of pesticide-resistant pests and breakdown of resistance. As a result of the negative environmental effects of overuse of chemical pesticides, alternative plant protection methods are becoming more attractive (Maroni et al. 2006). Use of biological control is an important approach in this regard. Plants also possess certain mechanisms to protect themselves against pathogens, which are enhanced by using specific compounds or microorganisms (Walters et al. 2009). This is a promising strategy for revitalizing plant defense and controlling plant diseases (Vallad and Goodman 2004). The induction of systemic resistance occurs when biotic or abiotic stimuli activate the plant's defensive mechanism. The potential of utilizing natural inducers of plant disease resistance has gained a lot of interest in recent years. Induced resistance in certain crops has been reported in many studies, and its potential use in crop protection against fungal, bacterial and viral infections has been discussed (Elsharkawy et al. 2012).

Trichoderma spp. are employed for biological control against a variety of diseases, including T. viride, T. harzianum and $T$. virens, by activating various defensive mechanisms, including enzyme synthesis and secretion of antifungal chemicals, and secondary metabolites. They have been proven to dissolve phosphates and micronutrients, making them accessible to plants (Lorito et al. 2010).

The aim of this study was to evaluate the potential of certain biocontrol agents against development of powdery mildew disease in sunflower plants and to reveal the involved mechanisms in disease suppression.

\section{Methods}

\section{Isolation and identification of the causal pathogen}

Fungal isolates were collected from infected leaves in sunflower fields in four Egyptian governorates (Giza, Kafr El-Sheikh, El-Beheira (Abu El-Matamir), El-Beheira (Nubaria) and Gharbia). The causal fungus of powdery mildew was identified by morphological characteristics and molecular detection. Isolates were morphologically identified in the laboratory by measuring the size and form of conidia, conidiophores and foot cell (100 conidia from each isolates). A fine pointed dissecting needle was used to pick up several phases of the pathogen, which were then mounted in lactophenol, dyed with cotton blue and photographed. Conidia from pustules on each leaf were transferred to a drop of $\mathrm{KOH}$ solution ( $\mathrm{pH} 3.0$ ) on a pitted microscope slide, covered with a cover glass and examined under a compound microscope at 400 magnification to confirm the existence of fibrosin bodies and their morphology.

Five samples from each isolate were utilized for the multiplex PCR procedures. These samples were amplified by PCR using primer pairs G1/G2. According to the standard kits, fungal DNA was isolated from diseased leaves as well as mycelium scraped from infected leaves. Following the manufacturer's instructions, genomic DNA was extracted, using an extraction mini kit (REF 17371). The reaction mixture was $25 \mu \mathrm{l}$, including $12.5 \mu \mathrm{l}$ of $2 \mathrm{X}$ master mix (Taq polymerase $(0.1 \mathrm{U} / \mu \mathrm{l})$, dNTP $(500 \mu \mathrm{M})$, Tris-HCL (20 mM), KCL (100 mM), $\mathrm{MgCl}_{2}(3 \mathrm{mM})$, and stabilizer and enhancer), 10 pmol of each primer and $2 \mu \mathrm{l}$ of template DNA $(50 \mathrm{~g} / \mathrm{ml})$. Amplification was carried out in a thermocycler (Applied Bio-Rad, USA) with an initial denaturation at $94{ }^{\circ} \mathrm{C}$ for $5 \mathrm{~min}$, followed by 35 cycles of denaturation at $94{ }^{\circ} \mathrm{C}$ for $30 \mathrm{~s}$, primer annealing at $55^{\circ} \mathrm{C}$ for $1 \mathrm{~min}$ and extension at $72{ }^{\circ} \mathrm{C}$ for $10 \mathrm{~min}$. The amplified products were examined on a $1.5 \%$ agarose gel with ethidium bromide at a final concentration of $0.5 \mathrm{~g} /$ $\mathrm{ml}$ after PCR and photographed.

\section{Plants and biocontrol agents}

A local sunflower, cv Giza-20, was utilized in all the experiments. Strains of Bacillus subtilis and B. pumilus, previously isolated from cucumber and squash leaves and identified by Kamel (2003), were used, whereas the strains of Trichoderma harzianum, T. viride and T. koningii were obtained from the Microbiology Department, Soil, Water, and Environment Research Institute, Agricultural Research Center, Giza, Egypt.

\section{Preparation of bacterial suspension}

Shaking flask submerged cultures were used to grow $B$. subtilis and B. pumilus on nutrient broth medium. Conical flasks $(500 \mathrm{ml})$ were inoculated with $1 \mathrm{ml}$ bacterial inocula from a 1-day-old culture and incubated for $72 \mathrm{~h}$ at $28 \pm 2{ }^{\circ} \mathrm{C}$ in a rotary shaking incubator $(120 \mathrm{rpm} / \mathrm{m})$. Density of the bacterial suspension was set to $10^{8} \mathrm{cfu} /$ $\mathrm{ml}$ (Sun et al. 2013). T. harzianum, T. viride and T. koningii were cultivated for 7 days in a liquid potato dextrose broth medium (PDB). Using a hemocytometer slide, the number of spores was adjusted to $10^{7}$ spores $\mathrm{ml}^{-1}$. The sunflower plants were foliar sprayed by the obtained suspensions.

\section{Experimental design}

Sunflower seeds cv. Giza-20 were planted under field conditions in a randomized complete block design (RCBD) with three repetitions. The experimental unit was made up of five rows, each measuring $2 \mathrm{~m}$ long and $0.7 \mathrm{~m}$ wide. Within the row, plants were spaced $50 \mathrm{~cm}$ apart and fertilized with recommended concentrations of the Ministry of Agriculture and Land Reclamation. The five biocontrol agents' treatments and one fungicide (Vectra $10 \%$ SC) were applied as soon as the first symptom of powdery mildew on sunflower plants was observed. The 
treatments were repeated five times, with 7-day intervals. On the other hand, the untreated control plants were sprayed by tap water and used for comparison.

\section{Disease assessment}

During each of the two growing seasons, disease severity (DS \%) was measured 5 times with 7-day intervals, using the method of Mohibullah (1992). The scale of the disease ranged from 1 to 9 (Table 1). Disease severity was recorded on three lower, middle and upper leaves. Five plants were randomly selected from each plot and labeled for subsequent evaluations. Disease severity was calculated by the following formula (Liu et al. 2001):

$$
\% \text { Disease severity }=\frac{\sum n \times r}{5 N} \times 100
$$

where $n=$ number of plants in each numerical rate, $N=$ total number of plants multiplied by the maximum numerical rate, $r=5$.

The area under disease progress curve (AUDPC) for each treatment was calculated using the equation proposed by Pandey et al. (1989) as follows:

$$
\mathrm{AUDPC}=D\left[1 / 2\left(Y_{1}+Y_{K}\right)+Y_{2}+Y_{3}+\cdots Y_{(K-1}\right)
$$

where $D=$ time intervals (days between consecutive records), $Y_{1}+Y_{k}=$ sum of the first and the last disease scores, and $Y_{2}+Y_{3}+\cdots+Y_{(K-1)}=$ sum of all in between disease scores.

Efficacy of the treatments was calculated according to the following formula:

$$
\text { Efficacy } \%=\frac{\text { DS\% control }- \text { DS } \% \text { treatment }}{\text { DS\% control }} \times 100
$$

\section{Microscopic examination}

Light microscope (Leica DM1000) examination was used to study the mode of biocontrol agents' action on conidiophores and conidia of G. cichoracearum on naturally infected sunflower leaves with powdery mildew sampled at $24 \mathrm{~h}$ after treating with the tested biocontrol agents. Photographing by microscope was done at the Agric. Bot. Dept., Fac. of Agric., Kafrelsheikh Univ., Egypt.

\section{Determination of biochemical compounds}

For greenness evaluations in the fifth apical fully expanded leaf, the total chlorophyll content was measured using the SPAD-501 portable leaf chlorophyll meter (Minolta Corp) (Yadava 1986).

\section{Growth parameters \\ Plant height}

At 60 days post-planting, the plant height was measured (in $\mathrm{cm}$ ) from ground level to the point of attachment of the capitulum.

\section{Head diameter}

At 90 days following planting, the diameter of the head was measured (in $\mathrm{cm}$ ) using vernier calipers above the basal node.

\section{Stem diameter}

At 90 days following planting, the diameter of the stem was measured (in $\mathrm{cm}$ ) using vernier calipers immediately above the basal node.

\section{Number of leaves}

At 90 days following planting, the number of completely opened leaves from the base to the tip of the terminal bud was counted.

\section{Yield components}

Seed yield $(\mathrm{kg} / \mathrm{fed})$ was determined in the season end through weight of total yield product. Oil content was determined using Soxhlet method according to AOAC (1984). Random samples of 1000 seeds from each plant were sun-dried and weighted in grams.

\section{Statistical analysis}

WASP software was used to conduct an analysis of variance (ANOVA) on the data. To compare treatment means, the least significant difference (LSD) at a $5 \%$ level of significance was employed. Statistical product and service solutions software (SPSS 22) was used to perform principal component analysis (PCA) of plant growth parameters, yield components and biological substances. Factor loading matrix generated from a Varimax rotation

Table 1 Key of disease severity of sunflower powdery mildew

\begin{tabular}{lll}
\hline Grade & Description & Reaction \\
\hline 0 & No symptom of powdery mildew on leaves & Immune (I) \\
1 & Small scattered powdery mildew specks covering 1\% or less leaf area & Highly resistant (HR) \\
3 & Small powdery lesions covering 1 to $10 \%$ leaf area & Resistant (R) \\
5 & Powdery lesions enlarged covering 11 to 25\% leaf area & Moderately resistant (MR) \\
7 & Powdery lesions coalesce to form big patches covering 26 to $50 \%$ leaf area & Susceptible (S)
\end{tabular}


with Kaiser normalization main components was utilized for PCA.

\section{Results}

\section{Identification of the causal pathogen}

Infected leaves were collected from Giza (A), Kafr ElSheikh (B), El-Beheira (Abu El-Matamer) (C), El-Beheira (Nubaria) (D) and Gharbia (E) Governorates with typical symptoms of powdery mildew.

Powdery mildew development in the studied samples was mainly ectophytic, with a high intensity and nonsignificant differences in symptoms. Among the samples studied in this study, the telemorphic stage was not detected. The conidial and anamorphic features of the different types of G. cichoracearum were examined in all of the samples. The morphological characteristics of conidia, conidiophores and foot cells of five distinct isolates of the causal pathogen of sunflower powdery mildew obtained from various Governorates were evaluated (Table 2). Length of the conidia for all isolates varied from 13 to $20 \mu \mathrm{m}$, with isolate (A) from Giza governorate having the longest conidia (18 to $20 \mu \mathrm{m}$ ) and isolate (B) from Kafr El-Sheikh governorate having the shortest conidia (13 to $15 \mu \mathrm{m}$ ) (Table 2). Isolates $\mathrm{A}$ and $\mathrm{C}$, collected from Giza and El-Beheira (Abu El-Matamer) governorates, respectively, achieved the widest conidia in the display scale, as they both achieved the same result of $(7-9 \mu \mathrm{m})$, while isolate D from El-Beheira (Nubaria) achieved the narrowest conidia in the display scale $(6-7 \mu \mathrm{m})$ (Table 2). The findings of the study revealed some variations in the overall form of the conidia, with isolate A being closer to a cylindrical shape and isolates No. B, D and E (Gharbia) being closer to a barrel shape. Isolate $C$, on the other hand, was more elliptical in shape (Table 2). All of the isolates turned out to be in the form of a right angle or a right shape. In terms of conidiophore length, isolate $\mathrm{A}$ was the longest, measuring $35-66 \mu \mathrm{m}$, whereas isolate $C$ was the shortest, measuring 37-62 $\mu \mathrm{m}$ (Table 2). In the case of foot cell, all isolates were on a single height scale of 6-8 $\mathrm{m}$, and all isolates had the form of an advanced nipple (Table 2). The sexual phase was not identified during the test, because none of the isolates showed any of the ascospores.

The use of specific primers to characterize sunflower isolates yielded $418 \mathrm{bp}$ amplicon that was similar in all sunflower samples obtained from the five distinct locations (Fig. 1). All of the samples tested yielded single amplification products (418 bp amplicon) unique to $G$. cichoracearum, suggesting that the infection was caused by a single organism with no other infecting organisms(s).

\section{Effect of some biocontrol agents on the powdery mildew of sunflower}

The disease development on sunflower treatments and untreated controls was assessed using three parameters: final disease severity (FDS \%), area under disease progress curve (AUDPC) and efficacy \%. Trichoderma koningii was significantly effective in controlling powdery mildew disease in relative to Vectra $10 \%$ SC fungicide and control. This treatment revealed significant

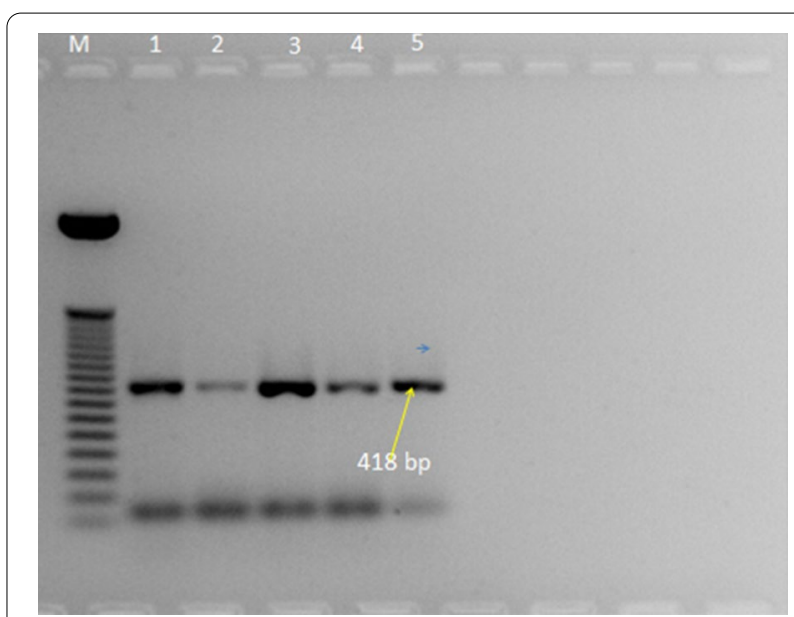

Fig. 1 PCR analysis of the DNA from Golovinomyces cichoracearum isolates collected from different geographical locations with universal G1/G2 primers (G1 (5'-TCC GTA GGT GAA CCT GCG GAA GGA T-3')/G2 (5'-CAA CAC CAA ACC ACA CAC ACG GCG -3')

Table 2 Dimensions and shapes of conidia, conidiophores and foot cell of different isolates of the causal agent of sunflower powdery mildew collected from different Governorates

\begin{tabular}{|c|c|c|c|c|c|c|c|}
\hline \multirow[t]{2}{*}{ Isolates } & \multicolumn{3}{|l|}{ Conidia } & \multicolumn{2}{|c|}{ Conidiophores } & \multicolumn{2}{|l|}{ Foot cell } \\
\hline & Length $\mu \mathrm{m}$ & Width $\mu \mathrm{m}$ & Shape & Length $\mu \mathrm{m}$ & Shape & Shape & Height $\mu \mathrm{m}$ \\
\hline 1 & $18-20$ & $7-9$ & Cylindrical & $35-66$ & Erect & Nipple-shaped, well-developed & $6-8$ \\
\hline 2 & $13-15$ & $6-8$ & Barrel & $36-64$ & Erect & Nipple-shaped, well-developed & $6-8$ \\
\hline 3 & $14-18$ & $7-9$ & Ellipsoidal & $37-62$ & Erect & Nipple-shaped, well-developed & $6-8$ \\
\hline 4 & $13-17$ & $6-7$ & Barrel & $36-65$ & Erect & Nipple-shaped, well-developed & $6-8$ \\
\hline 5 & 14-19 & $6-8$ & Barrel & $35-63$ & Erect & Nipple-shaped, well-developed & $6-8$ \\
\hline
\end{tabular}


decreases in (FDS), AUDPC and efficacy \% during the season of 2019 with values of 18.4, 260.4 and 78.4\%, respectively (Table 3 ). Likewise, the same treatment displayed significant decreases in (FDS\%), AUDPC and efficacy \% during the season of 2020 with respective values 20.1, 267.1 and 78.2. T. harzianum treatment resulted in reductions in FDS (19.9 and 22.6\%), AUDPC (284.3 and 295.1 ) and efficacy (76.6 and 75.5\%), than the control treatment, which displayed the highest values of FDS (85.0 and 92.4\%), AUDPC (837.5 and 1078.3) and efficacy (0.0 and 0.0\%) during the seasons 2019 and 2020, respectively.

\section{Microscopic examination}

Light microscope examinations showed that all treatments affected the size and shape as well as caused shrinking of treated hyphae, conidiophores and conidia of G. cichoracearum on naturally infected sunflower leaves with powdery mildew at $24 \mathrm{~h}$ post-treatment with biocontrol agents and fungicide (Fig. 2).

\section{Effect of certain treatments on the growth parameters of sunflower plants}

The obtained results indicated that the foliar application of all the tested treatments improved plant height $(\mathrm{cm})$, head diameter $(\mathrm{cm})$, stem girth $(\mathrm{cm})$ and the number of leaves of the treated sunflower plants in relation to untreated plants (control) (Table 4). Application of $T$. koningii revealed the highest significant increases in both seasons. The second treatment in promoting growth parameters was T. harzianum, where it recorded 230.0 and $222.0 \mathrm{~cm}$ of plant height, 26.3 and $23.3 \mathrm{~cm}$ of head diameter, 3.0 and $2.9 \mathrm{~cm}$ of stem girth and 40.5 and 36.0 of number of leaves in 2019 and 2020 seasons, respectively.

\section{Effect of certain treatments on yield components of sunflower plants}

Through the results presented in Table 5, it became clear that all the treatments under study had significant effects on improving yield components: seed yield $(\mathrm{kg} / \mathrm{fed})$, oil content (\%) and 1000-seed weight ( $\mathrm{g}$ ) of the treated sunflower plants relative to fungicide and untreated plants. The most significant treatment in improving yield components was $T$. koningii, where increased seed yield to 1208.0 and $1189.3 \mathrm{~kg} / \mathrm{fed}$, oil content to 44.7 and $42.3 \%$ and 1000-seed weight to 76.2 and $73.7 \mathrm{~g}$, during 2019 and 2020 seasons, respectively, than the control (798.6 and $772.3 \mathrm{~kg} / \mathrm{fed})$, (35.1 and 30.7\%) and (65.1 and $60.9 \mathrm{~g}$ ) of the three yield components during the same seasons.

\section{Characteristics of sunflower plants using principal component analysis (PCA)}

Principal component analysis was performed on disease parameters, plant growth parameters, yield components and biochemical compounds in response to sunflower powdery mildew (Fig. 3). The factor loading matrix generated from a Varimax rotation with Kaiser normalization of the main components was used to interpret the principal components (PCs) to find the variables for dataset grouping. As shown from scree plot graph of eigenvalues (Fig. 3), the first three components, i.e., FDS (\%), AUDPC and efficacy \%, had eigenvalues of more than one. Therefore, three components were extracted, describing approximately $95.251 \%$ in the pooled data of seasons 2019 and 2020 (Table 6). For the PC1, PC2 and PC3, all the disease parameters, plant growth parameters and yield components showed $76.305,86.635$ and $96.265 \%$ of the total variation in the pooled data of 2019 and 2020 seasons, respectively (Table 6 and Fig. 4).

Table 3 Effects of certain treatments on final disease severity (\%), area under disease progress curve (AUDPC) and efficacy (\%) for controlling powdery mildew disease of sunflower plants, during 2019 and 2020 seasons

\begin{tabular}{|c|c|c|c|c|c|c|}
\hline \multirow[t]{2}{*}{ Treatment } & \multicolumn{2}{|l|}{ FDS\% } & \multicolumn{2}{|c|}{ AUDPC } & \multicolumn{2}{|c|}{ \% Efficacy } \\
\hline & 2019 & 2020 & 2019 & 2020 & 2019 & 2020 \\
\hline Bacillus subtilis & 25.1 & 28.0 & 316.1 & 321.5 & 70.5 & 69.7 \\
\hline Bacillus pumilus & 28.3 & 30.0 & 365.3 & 375.2 & 66.7 & 67.5 \\
\hline Trichoderma harzianum & 19.9 & 22.6 & 284.3 & 295.1 & 76.6 & 75.5 \\
\hline Trichoderma viride & 30.5 & 35.0 & 445.5 & 483.5 & 64.10 & 62.1 \\
\hline Trichoderma koningii & 18.4 & 20.1 & 260.4 & 267.1 & 78.4 & 78.2 \\
\hline Vectra $10 \%$ SC & 10.3 & 12.3 & 128.1 & 145.1 & 87.8 & 86.7 \\
\hline Control & 85.0 & 92.4 & 837.5 & 1078.3 & 0.0 & 0.0 \\
\hline $\begin{array}{l}\mathrm{LSD}_{0.05} \text { of interaction (treat- } \\
\text { ment * years) }\end{array}$ & 2.03 & & 8.67 & & 2.13 & \\
\hline
\end{tabular}



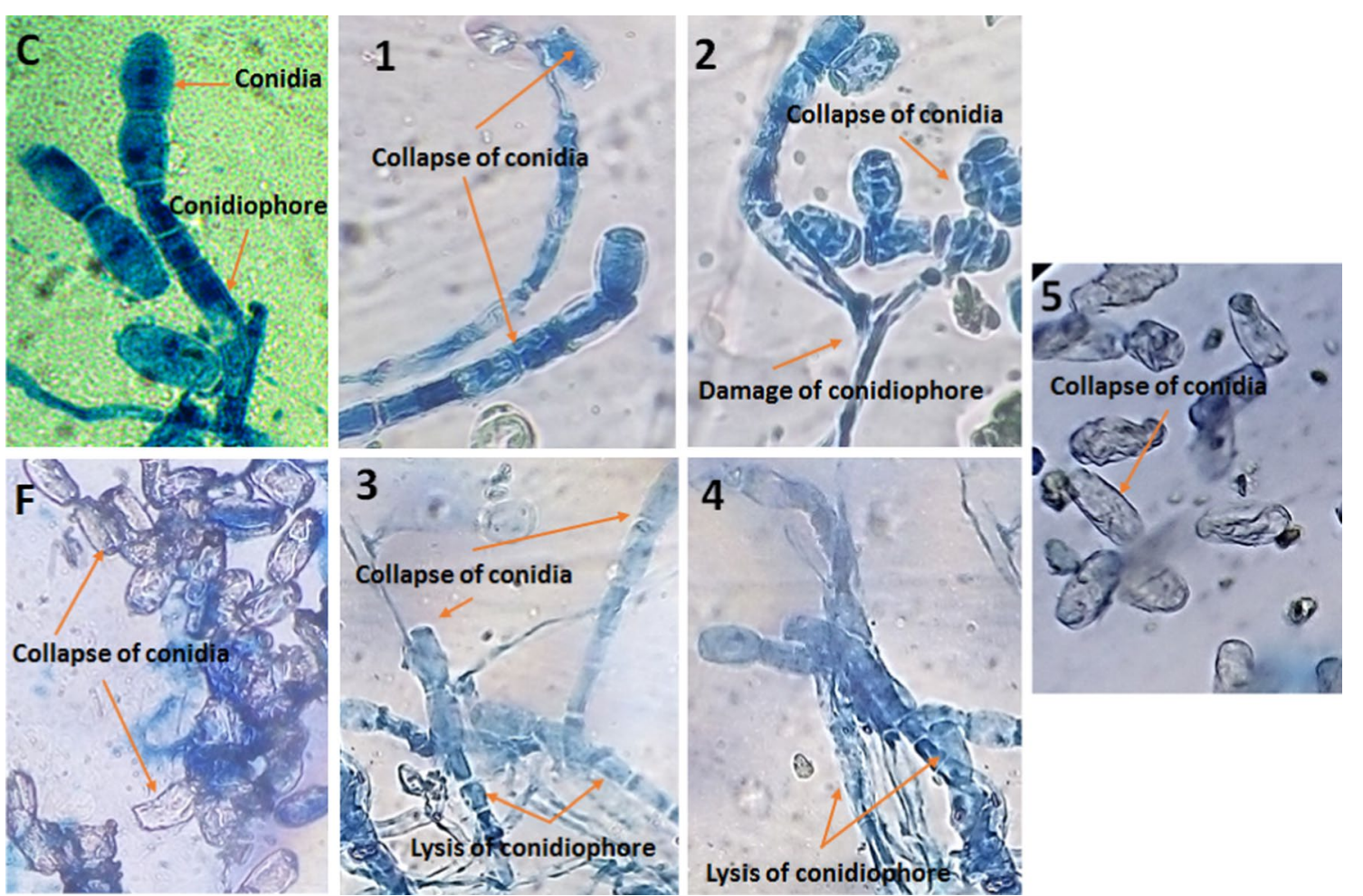

Fig. 2 Light microscope observations of hyphae, conidiophores and conidia of Golovinomyces cichoracearum collected from sunflower leaf surface sprayed with all treatments showing, C: untreated control with normal conidia and conidiophores. 1: Bacillus subtilis, 2: B. pumilus, 3: Trichoderma harzianum, 4: T. viride, 5: T. koningii and F: fungicide (Vectra) showing twisting and lysis of hyphae and conidiophores and conidial shrinking and collapsing, $(400 x)$

Table 4 Effects of certain treatments on growth parameters of sunflower plants against powdery mildew disease during 2019 and 2020 seasons

\begin{tabular}{|c|c|c|c|c|c|c|c|c|}
\hline \multirow[t]{2}{*}{ Treatment } & \multicolumn{2}{|c|}{ Plant height $(\mathrm{Cm})$} & \multicolumn{2}{|c|}{ Head diameter $(\mathrm{cm})$} & \multicolumn{2}{|c|}{ Stem girth $(\mathrm{cm})$} & \multicolumn{2}{|c|}{ Number of leaves } \\
\hline & 2019 & 2020 & 2019 & 2020 & 2019 & 2020 & 2019 & 2020 \\
\hline Bacillus subtilis & 221.0 & 215.2 & 25.1 & 22.0 & 2.9 & 2.6 & 37.3 & 34.6 \\
\hline Bacillus pumilus & 208.0 & 201.4 & 23.3 & 21.0 & 2.6 & 2.4 & 35.6 & 31.0 \\
\hline Trichoderma harzianum & 230.0 & 222.0 & 26.3 & 23.3 & 3.0 & 2.9 & 40.5 & 36.0 \\
\hline Trichoderma viride & 190.6 & 181.6 & 22.9 & 19.0 & 2.4 & 2.1 & 32.1 & 29.0 \\
\hline Trichoderma koningii & 240.0 & 235.1 & 27.1 & 24.0 & 3.2 & 3.0 & 41.0 & 38.0 \\
\hline Vectra $10 \%$ SC & 255.6 & 251.1 & 29.3 & 28.1 & 3.3 & 3.2 & 40.3 & 41.0 \\
\hline Control & 168.3 & 171.6 & 19.6 & 17.9 & 2.0 & 1.8 & 25.4 & 22.0 \\
\hline $\begin{array}{l}\mathrm{LSD}_{0.05} \text { of interaction (treat- } \\
\text { ment * years) }\end{array}$ & 7.64 & & 2.67 & & 0.43 & & 2.53 & \\
\hline
\end{tabular}

\section{Discussion}

In sunflower, G. cichoracearum is more common pathogen than Podosphaera xanthii in producing powdery mildew. The conidia-exhibited morphological features were comparable to G. cichoracearum.
G. cichoracearum was the most likely identified pathogen in this study. To establish the presence of $G$. cichoracearum on a molecular level, genetic identification was performed. Ascospores were not found. Similarly, Chen et al. (2008) found out that the 
Table 5 Effects of certain treatments on yield components of sunflower plants against powdery mildew disease of sunflower pants during 2019 and 2020 seasons

\begin{tabular}{|c|c|c|c|c|c|c|}
\hline \multirow[t]{2}{*}{ Treatment } & \multicolumn{2}{|c|}{ Seed yield (kg/fed) } & \multicolumn{2}{|c|}{ Oil content (\%) } & \multicolumn{2}{|c|}{ 1000-seed weight (g) } \\
\hline & 2019 & 2020 & 2019 & 2020 & 2019 & 2020 \\
\hline Bacillus subtilis & 1153.5 & 1107.3 & 40.5 & 38.5 & 68.2 & 63.6 \\
\hline Bacillus pumilus & 1115.0 & 1061.6 & 40.0 & 35.2 & 63.3 & 60.3 \\
\hline Trichoderma harzianum & 1188.3 & 1164.0 & 43.3 & 40.2 & 71.9 & 70.3 \\
\hline Trichoderma viride & 1003.6 & 1009.0 & 38.3 & 32.1 & 60.9 & 56.0 \\
\hline Trichoderma koningii & 1208.0 & 1189.3 & 44.7 & 42.3 & 76.2 & 73.7 \\
\hline Vectra $10 \%$ SC & 1297.0 & 1273.0 & 46.5 & 44.1 & 81.3 & 80.8 \\
\hline Control & 798.6 & 772.3 & 35.1 & 30.7 & 65.1 & 60.9 \\
\hline $\begin{array}{l}\mathrm{LSD}_{0.05} \text { of interaction (treat- } \\
\text { ment * years) }\end{array}$ & 9.23 & & 1.21 & & 2.10 & \\
\hline
\end{tabular}

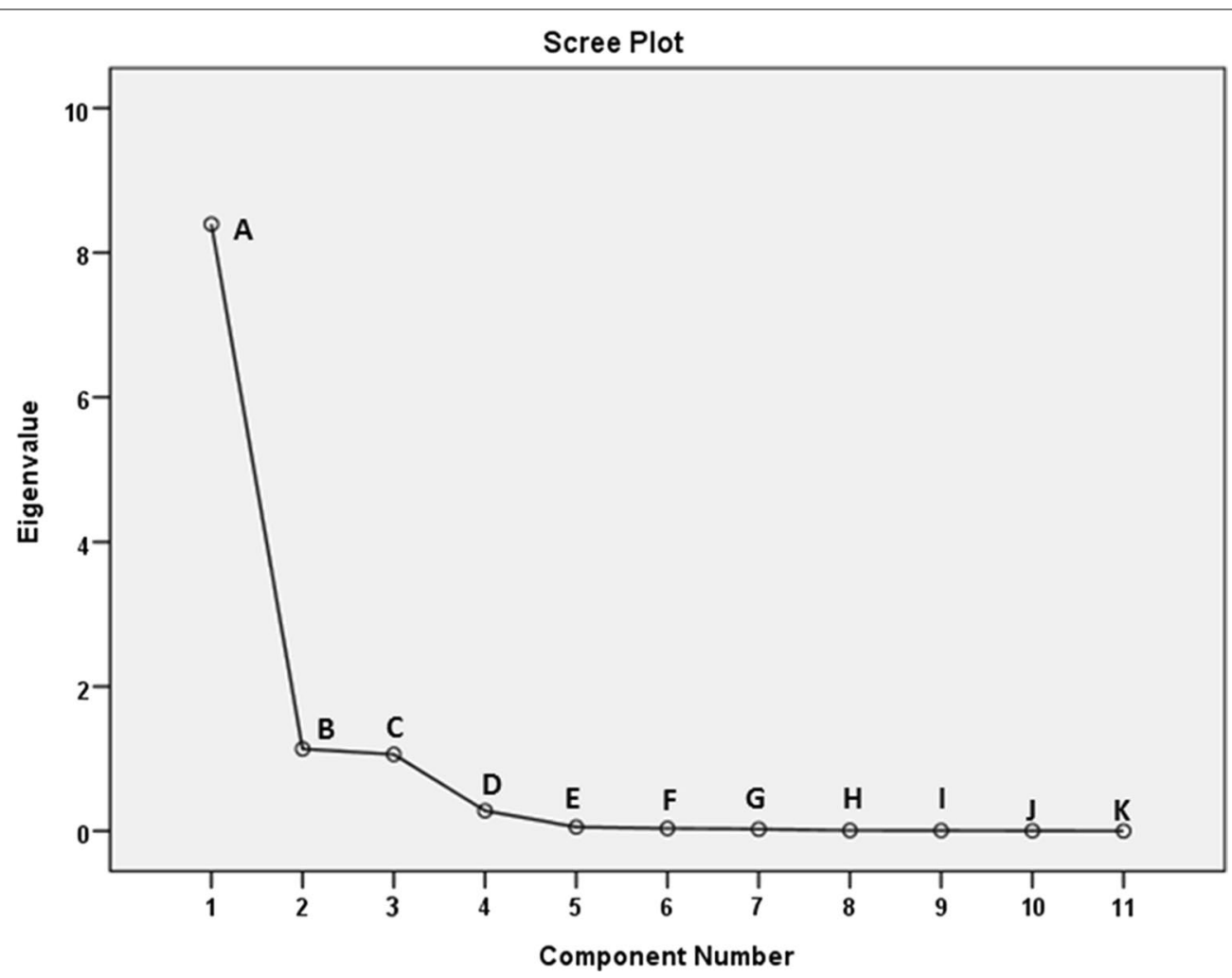

Fig. 3 The scree plot of eigenvalue for the component number of disease parameters, plant growth parameters and yield components in response to sunflower powdery mildew in the pooled data of 2019 and 2020 seasons. Details—A: FDS (\%), B: AUDPC, C: efficacy \%, D: chlorophyll ( $\mu \mathrm{g} / \mathrm{cm} 2)$, E: plant height, F: head diameter, G: stem girth, H: number of leaves, I: seed yield (kg/fed), J: oil content (\%) and K: 1000-seed weight (g)

morphological analysis of all isolates revealed that none of the sexual phase was present. Due to differences between these isolates of G. cichoracearum, the multiplex PCR technique established in this research was a useful diagnostic tool for distinguishing this powdery mildew and detecting the existence on the host plant tissue (Chen et al. 2008). In the aforementioned tests,
G. cichoracearum was most likely the causal agent of powdery mildew infection.

It is well known that biological control agents studied so far do not have the same effectiveness as chemical control agents in controlling powdery mildews. As a result, it is critical to develop biological management, while also reducing the usage of chemicals to control 
Table 6 Loadings between the first two principal components of disease parameters, plant growth parameters and yield components extracted from Varimax with Kaiser normalization for sunflower powdery mildew disease in the pooled data of 2019 and 2020 seasons

\begin{tabular}{|c|c|c|c|c|c|c|}
\hline \multirow[t]{3}{*}{ Component } & \multicolumn{6}{|c|}{ Total variance explained } \\
\hline & \multicolumn{3}{|c|}{ Initial eigenvalues } & \multicolumn{3}{|c|}{ Extraction sums of squared loadings } \\
\hline & Total & $\%$ of Variance & Cumulative \% & Total & $\%$ of Variance & Cumulative \% \\
\hline FDS\% & 8.394 & 76.309 & 76.309 & 8.394 & 76.309 & 76.309 \\
\hline AUDPC & 1.136 & 10.325 & 86.635 & 1.136 & 10.325 & 86.635 \\
\hline \% Efficacy & 1.060 & 9.633 & 96.268 & 1.060 & 9.633 & 96.268 \\
\hline Chlorophyll $\left(\mu \mathrm{g} / \mathrm{cm}^{2}\right)$ & 0.280 & 2.543 & 98.811 & & & \\
\hline Plant height (Cm) & 0.054 & 0.494 & 99.305 & & & \\
\hline Head diameter (cm) & 0.036 & 0.326 & 99.631 & & & \\
\hline Stem girth $(\mathrm{cm})$ & 0.025 & 0.231 & 99.862 & & & \\
\hline Number of leaves & 0.008 & 0.071 & 99.934 & & & \\
\hline Seed yield (kg/fed) & 0.006 & 0.051 & 99.985 & & & \\
\hline Oil content (\%) & 0.002 & 0.015 & 100.000 & & & \\
\hline 1000-seed weight (g) & $4.680 \mathrm{E}-5$ & 0.000 & 100.000 & & & \\
\hline
\end{tabular}

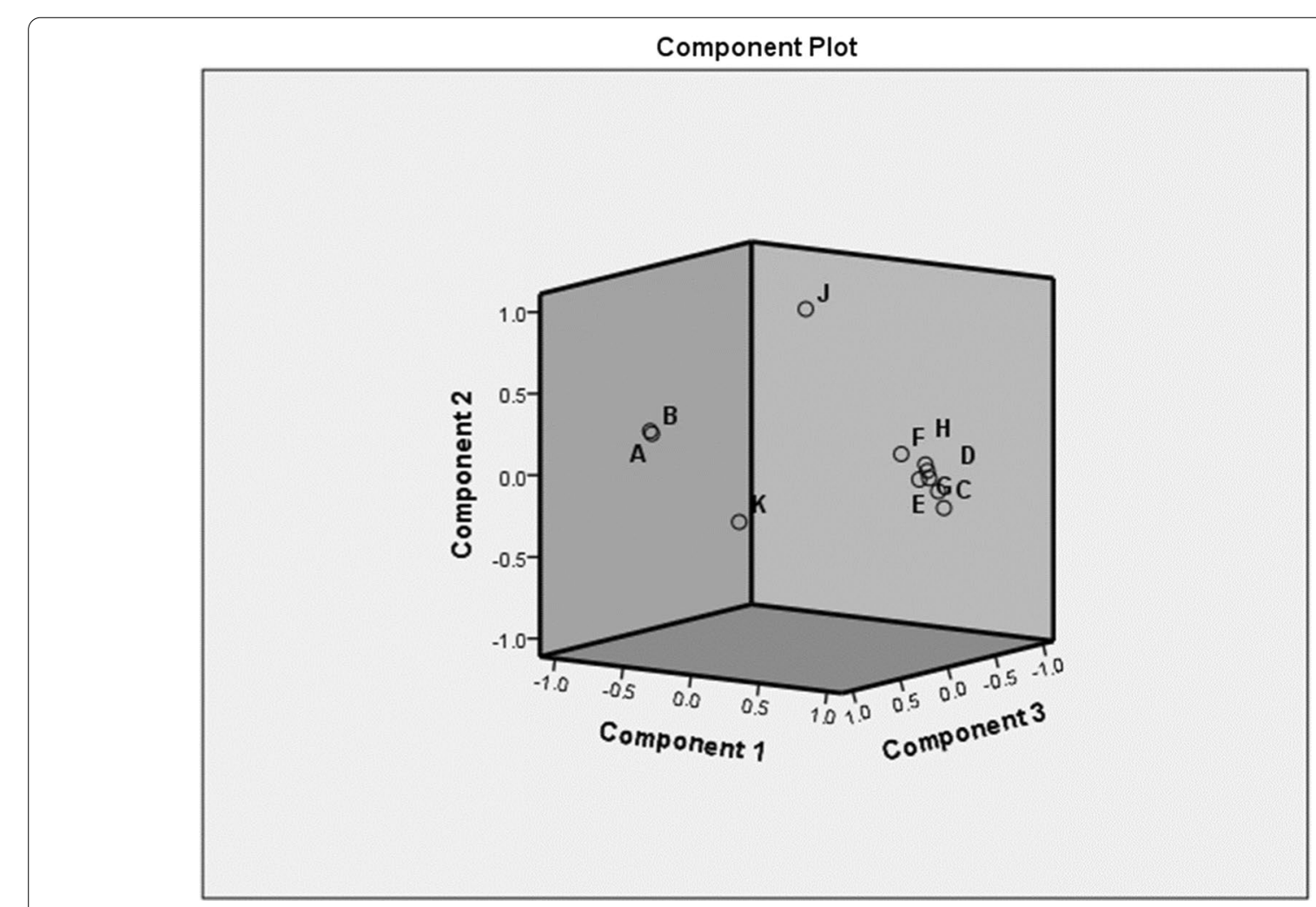

Fig. 4 Loadings plot of PC1, PC2 and PC3 for the component number of disease parameters, plant growth parameters and yield components in response to sunflower powdery mildew disease in the pooled data of 2019 and 2020 seasons. Details_A: FDS (\%), B: AUDPC, C: efficacy \%, D: Chlorophyll ( $\mu \mathrm{g} / \mathrm{cm} 2)$, E: plant height, F: head diameter, G: stem girth, H: number of leaves, l: seed yield (kg/fed), J: oil content (\%) and K: 1000-seed weight (g) 
powdery mildew. When compared to the control treatment, all treatments substantially lowered the three parameters (final disease severity (FDS\%), area under disease progress curve (AUDPC) and efficacy (\%)). The fungicide treatment was the most successful in suppressing powdery mildew, followed by $T$. koningii as a biological control agent; the control had the most severe powdery mildew. Trichoderma spp. may have these effects, because they produce a diverse range of antifungal enzymes that attack the pathogen's outer coat (Harman, 2006). Furthermore, B. subtilis produces a variety of antibiotics which inhibit plant pathogens (Omara et al. 2020), resulting in decreasing the inoculums of the pathogenic spores. Thus, these treatments reduce disease severity and the development of area under the disease progress curve and increase the efficiency of disease resistance (Omara et al. 2020).

The control mechanisms and impacts of employing biocontrol agents to control G. cichoracearum should be elucidated. The biocontrol agents reduced powdery mildew infection in sunflower. The technique of employing T. koningii produced a substantially superior outcome. When compared to the controls, the isolate T. koningii offered substantial control of powdery mildew, although it was less effective than the traditional fungicide. These findings indicate that $T$. koningii may be a part of an integrated disease management strategy that includes moderately resistant cultivars or low concentrations of suitable fungicides. The light microscope images showed that the powdery mildew conidiophores have been lysed, and the conidia have been collapsed as a result of the bioagent treatments. The bioagents colonized and lysed both the spores and hyphae of the powdery mildew fungus on the leaves at $24 \mathrm{~h}$ after treatment. The capacity of the bioagent inoculum to colonize and proliferate on the pathogen host would raise the bioagent inoculum level above that applied to the plant. Longer-term control may be enhanced by the increasing bioagent population. The application of Trichoderma spp. and B. subtilis had significant effects on increasing plant resistance to pathogens by encouraging and stimulating the production of enzymes (Omara et al. 2020).

When comparing the biocontrol agents to the control, there was also evidence of enhancing growth and yield parameters. The effect of certain antagonistic microorganisms as growth regulators was elucidated (Elsharkawy and El-Khateeb 2019). These biocontrol agents have been proven to boost plant growth directly or indirectly. They may help plants absorb nutrients by solubilizing them. Trichoderma spp. are now being utilized in plant agriculture in quite considerable numbers, both for disease control and for yield enhancement (Harman 2006). It is possible that Trichoderma isolates have high capacities to enhance plant nutrient absorption, making them more efficient and competitive in terms of growth and development than many other soil microorganisms (Benitez et al. 2004). Certain Bacillus species generate extracellular metabolites with antibiotic action, such as lipopeptides and peptides, which may be employed as antagonists or growth promoters (Omara et al. 2020). Additionally, the synthesis of plant growth regulators, such as indoleacetic acid, gibberellins and cytokinin, by biological control agents results in plant growth stimulation and increases in yield (Singh et al. 2018).

It is important to combine the data and limit the parameters to find the smallest dataset that can explain the overall variance. For screening huge quantities of breeding materials, Abu Aly et al. (2017) found that FRS (\%) and ACI were more suitable indicators than AUDPC. Their conclusion was that there were more readily applied or handled for breeders to simplify the selection process during a national breeding program without taking up additional time.

\section{Conclusions}

Golovinomyces cichoracearum was the most likely fungus that caused the powdery mildew symptoms in this research. Biocontrol treatments were able to prevent or decrease powdery mildew infections in sunflower plants to an acceptable level. When compared to the untreated control, a biological control agent had a substantially superior impact. The use of biocontrol agents led to a significant increase in the growth parameters than the control.

\section{Abbreviations \\ AUDPC: Area under disease progress curve; FDS: Final disease severity; PDB: \\ Potato dextrose broth medium; PCA: Principal component analysis.}

\section{Acknowledgements}

The authors greatly acknowledge the staff of Department of Agricultural Botany, Faculty of Agriculture, Kafrelsheikh University, Kafr El-Sheikh, Egypt.

\section{Authors' contributions}

EAA, KMM, FFM, ENMM and EMM carried out the experiments. EAA, ORI and EMM wrote the manuscript. EMM revised the manuscript. All authors read and approved the final manuscript.

\section{Funding}

Funding is by the authors.

\section{Availability of data and materials}

All data and materials are available.

\section{Declarations}

Ethics approval and consent to participate Not applicable. 
Consent for publication

Not applicable.

\section{Competing interests}

The authors declare that they have no competing interests.

\section{Author details}

'Plant Pathology Research Institute, Agriculture Research Center (ARC), Giza, Egypt. ${ }^{2}$ Agricultural Botany Department, Faculty of Agriculture, Kafrelsheikh University, Kafr El-Sheikh, Egypt.

Received: 16 July 2021 Accepted: 25 September 2021

Published online: 04 October 2021

\section{References}

Abu Aly AAM, Omara RI, Abd El-Malik Nagwa I (2017) Evaluation of new sources of resistance to wheat stripe rust (Puccinia striiformis f. sp. tritici), under Egyptian field conditions. J Plant Prot Path Mansoura Univ 8(4):181-188

AOAC (1984) Official methods of analysis, 14th edn. Association of Official Analytical Chemists (AOAC), Arlington

Benitez T, Rincón AMM, Limón C, Codón AC (2004) Biocontrol mechanisms of Trichoderma strains. Int Microbiol 7:249-260

Chen RS, Chu C, Cheng CW, Chen WY, Tsay JG (2008) Differentiation of two powdery mildews of sunflower (Helianthus annuus) by a PCR-mediated method based on ITS sequences. Eur J Plant Pathol 121:1-8

Elsharkawy MM, El-Khateeb NM (2019) Antifungal activity and resistance induction against Sclerotium cepivorum by plant growth-promoting fungi in onion plants. Egypt J Biol Pest Control 29:68

Elsharkawy MM, Shimizu M, Takahashi H, Hyakumachi M (2012) Induction of systemic resistance against Cucumber mosaic virus by Penicillium simplicissimum GP17-2 in Arabidopsis and tobacco. Plant Pathol 61:964-976

Grote D, Olmos A, Kofoet A, Tuset JJ, Bertolini E, Cambra M (2002) Specific and sensitive detection of Phytophthora nicotianae by simple and nested-PCR. Eur J Plant Pathol 108:197-207

Harman GE (2006) Overview of mechanisms and uses of Trichoderma spp. Phytopathology 96:190-194

Kamel SMH (2003) Antagonistic effects of some microbial inhabitants on phylloplane of squash plants towards Sphaerotheca fuliginea. M.Sc. thesis, Faculty of Agriculture, Tanta University, Egypt, p 94

Kashimoto K, Matsuda Y, Kakutani K, Sameshima T, Kakutani K, Nonomura T et al (2003) Morphological and molecular characterization for a Japanese isolate of tomato powdery mildew Oidium neolycopersici and its host range. J Gen Plant Pathol 69:176-185

Liu SX, Griffey CA, Maroof MAS (2001) Identification of molecular markers associated with adult plant resistance to powdery mildew in common wheat cultivar Massey. Crop Sci 41:1268-1275

Lorito M, Woo SL, Harman GE, Monte E (2010) Translation on Trichoderma: from omics to the field. Ann Rev Phytopathol 48:395-417

Maroni M, Fanetti AC, Metruccio F (2006) Risk assessment and management of occupational exposure to pesticides in agriculture. Med Lav 97:430-434

Mohibullah (1992) Studies on major diseases of bulb vegetables (onion and garlic) in NWFP. Final Technical Report, Agricultural Research Institute, Tamab

Omara RI, Essa TA, Khalil AA, Elsharkawy MM (2020) A case study of nontraditional treatments for the control of wheat stem rust disease. Egypt J Biol Pest Control 30:83

Pandey HN, Menon TCM, Rao MV (1989) A simple formula for calculating area under disease progress curve. Rachis 8(2):38-39

Singh AK, Kumar A, Singh PK (2018) PGPR amelioration in sustainable agriculture. Food security and environmental management, 1st edn. Woodhead Publishing, Sawston, p 284

Sudisha J, Niranjana SR, Sukanya SL, Girijamba R, Lakshmi Devi N, Shetty HS (2010) Relative efficacy of strobilurin formulations in the control of downy mildew of sunflower. J Pest Sci 83:461-470

Sun ZB, Yuan XF, Zhang H, Wu LF, Liang C, Feng YJ (2013) Isolation, screening and identification of antagonistic downy mildew endophytic bacteria from cucumber. Eur J Plant Pathol 137:847-857

Vallad GE, Goodman GR (2004) Systemic acquired resistance and induced systemic resistance in conventional agriculture. Rev Int Crop Sci 44:1920-1934

Walters DR, Paterson L, Walsh DJ, Havis ND (2009) Priming for plant defense in barley provides benefits only under high disease pressure. Physiol Mol Plant Pathol 73:95-100

Yadava UL (1986) A rapid and non-destructive method to determine chlorophyll in intact leaves. Hort Sci 21:1449-1450

\section{Publisher's Note}

Springer Nature remains neutral with regard to jurisdictional claims in published maps and institutional affiliations.

\section{Submit your manuscript to a SpringerOpen ${ }^{\odot}$ journal and benefit from:}

- Convenient online submission

- Rigorous peer review

- Open access: articles freely available online

- High visibility within the field

- Retaining the copyright to your article

Submit your next manuscript at springeropen.com 